\title{
Estrous Cycle Response in Mice (Mus musculus) with CSE (Crude Sperm Extract) Injected Intraperitoneally
}

\author{
Enni Mutiati ${ }^{1}$, Sri Rahayu ${ }^{2}$, Gatot Ciptadi ${ }^{3}$, Moch. Nasich ${ }^{3}$ \\ ${ }^{1}$ Master Program of Biology, Faculty of Mathematics and Natural Sciences, University of Brawijaya, Malang, Indonesia \\ ${ }^{2}$ Department of Biology, Faculty of Mathematics and Natural Sciences, University of Brawijaya, Malang, Indonesia \\ ${ }^{3}$ Department of Animal Production, Faculty of Animal Husbandry, University of Brawijaya, Malang, Indonesia
}

\begin{abstract}
Sperm protein has an important role in fertilization process. It becomes antigenic when it is injected to body and can increase TNF- $\alpha$ secretion. TNF- $\alpha$ in blood vesssel can inhibit estradiol synthesis. Estradiol has a significant role in repduction cycle, especially in estrous cycle. The study aims to understand the influence of Crude Sperm Extract (CSE) to mice (Mus musculus) estrous cycle. 16 fertile mices strain Balb-C aged 3-4 months, weighed 20-30 g was divided into 4 groups. $\mathrm{P}_{0}$ is a control group injected by $\mathrm{PBS}$, group $\mathrm{P}_{1}, \mathrm{P}_{2}$, and $\mathrm{P}_{3}$ injected by CSE with $1.5 \mathrm{mg}^{\mathrm{ml}} \mathrm{ml}^{-1}, 2 \mathrm{mg} \cdot \mathrm{ml}^{-1}$, and 2.5 $\mathrm{mg} \cdot \mathrm{ml}^{-1}$. CSE is injected intraperitoneally during mice's diestrus phase. CSE is injected in day 0, day 12, day 24 and observed daily. The data are descriptively analyzed. The results show that CSE with molecule weight between 26.8$176.8 \mathrm{kDa}$ influences estrous cycle.
\end{abstract}

Keywords: Crude Sperm Extract, estrous cycle, folliculogenesis, Mus musculus

\section{INTRODUCTION}

Sperm protein plays an important role in the fertilization process. It becomes antigenic when injected to body and causes immune responses $[1,2,3]$. Sperm protein will increase the secretion of TNF-a by macrophages-activated CD4 T cells $[4,5]$.

TNF- $\alpha$ will bind to TNF- $\alpha$ receptor in the ovary [6], thus inhibit the synthesis of estradiol through cAMP (Adenosine-3', $5^{\prime}$ - Cyclic Monophosphate) and PKA (protein kinase A) pathway. CAMP and PKA are involved in cytochrome P450scc excretion that convert cholesterol to pregnenolon, and eventually estradiol biosynthesis and metabolism [7,8]. Estradiol has a significant role in estrous cycle [9]. Based on the mentioned facts and reasons, the present study aims to understand the influence of Crude Sperm Extract (CSE) in mice estrous cycle.

\section{MATERIALS AND METHODS}

Isolation and Charaterization of Bull's Sperm Protein

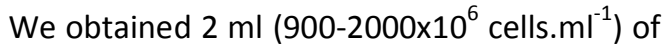
bull's sperm from BBIB (Balai Besar Inseminasi Buatan - Center for Artificial Insemination). The sperm was washed with $6 \mathrm{ml}$ PBS (phosphate

\footnotetext{
* Correspondence author:

Enni Mutiati

Email : enni.mutiati@gmail.com

Address : Master Program of Biology, University of Brawijaya, Jl. Veteran Malang, 65145
}

buffer saline), vortexed and centrifuged (2500rpm, 10 minutes). The pellet was resuspended with $3 \mathrm{ml} \mathrm{TCM}$ (Tissue Culture Medium) then vortexed and centrifuged once more (2500rpm, 10 minutes). The pellet was resuspended with $0.5 \mathrm{ml}$ extract buffer and coldsonicated (50\% amplitude, 20 minutes). Total 1 $\mathrm{ml}$ suspension was centrifuged $(9000 \mathrm{rpm}, 30$ minutes, $4^{\circ} \mathrm{C}$ ) and result's $0.5 \mathrm{ml}$ supernatant was further centrifuged $\left(13.000 \mathrm{rpm}, 45\right.$ minutes, $4^{\circ} \mathrm{C}$ ) and then resuspended with KCL-HEPES buffer $(1: 1)$ and stored in $-80^{\circ} \mathrm{C}$ [10]. The isolated sperm protein was characterized with $12.5 \%$ separating gel SDS-PAGE protocol [11].

\section{Animal Treatment}

Total of 16 fertile female mice (Mus musculus) strain Balb-C, aged 3-4 months and weighed 20-30 g were used as animal model in this study. They were divided into 4 groups: control group $\left(P_{0}\right)$ without CSE injection; $P_{1}$ which injected with $1.5 \mathrm{mg} \cdot \mathrm{ml}^{-1} \mathrm{CSE} ; \mathrm{P}_{2} 2 \mathrm{mg} \cdot \mathrm{ml}^{-1}$ CSE injection; and $P_{3} 2.5 \mathrm{mg}^{-\mathrm{ml}^{-1}}$ CSE injection. All injections were all intraperitonal and administered at $0^{\text {th }}$ day, $12^{\text {th }}$ day and $24^{\text {th }}$ day of experiment. CSE is injected intraperitoneally during mice's diestrus phase.

\section{Estrous cycle observation}

The observation of estrous cycle was conducted since $0^{\text {th }}$ until $24^{\text {th }}$ days that covers proestrus, estrous, metestrus dan diestrus periods. Vaginal smears were made by using pipette 
with $\mathrm{NaCl} 0.9 \%$ solution. The lenght of estrous cycle was descriptively analyzed.

\section{RESULT AND DISCUSSION}

SDS-PAGE characterization reveals that Bull's sperm CSE have 11 protein bands with molecule size 176.8, 63.2, 58.4, 55.3, 52.4, 49.7, 44.6, $38.02,36.03,34.1$ and $26.8 \mathrm{kDa}$ [12]. These protein bands were all used for treatment in mice.

We identified the phases of mice estrous cycle by its general criteria (Fig. 1). In proestrus phase, vaginal cytology dominated by parabasal cells and estrous phase vaginal cytology dominated by superficial cells. Intermediate and parabasal cells predominate in smears taken during metestrus. The onset of diestrus is marked by a precipitous decline in the number of superficial cells and reappearance of intermediate and parabasal cells [13].
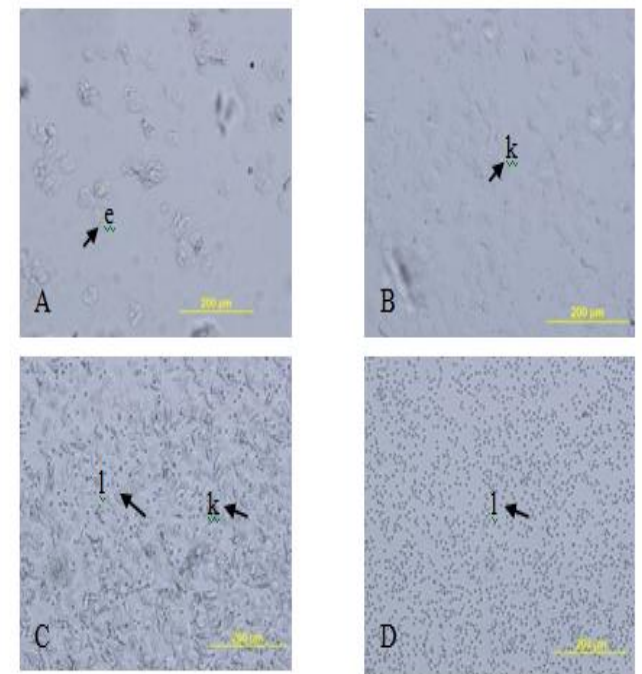

Figure 1. Vaginal cytology representing each stage of estrous cycle

Description:

A. Proestrus, nucleated epithelial cells (e)

B. Estrous, cornification cell ( $\mathrm{k}$ )

C. Metestrus, cornification cell (k) and leukocyte cell (I)

D. Diestrus, dominated by leukocytes (I).
Estrous cycle signifies sexual activity and organ function, like the function of the ovarium, along with follicle development. We found irregularity in CSE injected group. It characterized by elongation of time in one phase of the estrous cycle, which is diestrus (Table 1, Fig. 2).

Table 1. Average Length of Estrous Cycle Stages on Three Cycles

\begin{tabular}{lcccc}
\hline \multirow{2}{*}{ Phase (day) } & \multicolumn{4}{c}{ Treatment } \\
\cline { 2 - 5 } & $\mathbf{P}_{\mathbf{0}}$ & $\mathbf{P}_{\mathbf{1}}$ & $\mathbf{P}_{\mathbf{2}}$ & $\mathbf{P}_{\mathbf{3}}$ \\
\hline Proestrus & $1.0 \pm 0.0$ & $1.0 \pm 0.0$ & $1.0 \pm 0.0$ & $1.0 \pm 0.0$ \\
Estrous & $1.0 \pm 0.0$ & $1.0 \pm 0.0$ & $1.0 \pm 0.0$ & $1.0 \pm 0.0$ \\
Metestrus & $1.0 \pm 0.0$ & $1.0 \pm 0.0$ & $1.0 \pm 0.0$ & $1.5 \pm 0.58$ \\
Diestrus & $2.8 \pm 0.7$ & $3.1 \pm 0.6$ & $4.1 \pm 0.8$ & $4.3 \pm 1.6$ \\
\hline
\end{tabular}

The data signify that CSE could influence the estrous cycle length, which have elongation in diestrus phase compared to control ( $\left.\mathrm{P}_{0}\right)$ (Fig. 2). The elongation tendencies of diestrus phase in each treatment are 3 days longer $\left(P_{1}\right), 4$ days $\left(P_{2}\right)$, and 4-5 days $\left(P_{3}\right)$ (Fig. 3). The average duration of normal estrous cycle in mice and rats is 4-5 days [14]. CSE injection in the body may cause immune responses and eventually increase TNF$\alpha$ secretion in blood by CD4 T cells which are activated by macrophages [2-5]. TNF- $\alpha$ through the blood vessels will bind to TNF- $\alpha$ receptor in the ovary [6].

The increase of cytokine TNF- $\alpha$ in the ovarian inhibit synthesis of estradiol through inhibition of CAMP and PKA pathway. CAMP and PKA involved in regulating the expression of the enzyme cytochrome P450scc. P450scc cytochrome enzymes will convert cholesterol to pregnenolone. Pregnenolone be converted to estradiol [7].

Inhibition of CAMP and PKA will inhibit the enzyme P450scc, so it will inhibit the biosynthesis and metabolism of Estradiol [8]. Inhibition of estradiol can delay the replacement of diestrus phase to the proestrus phase, because the proestrus phase has estradiol in highest levels and the diestrus phase has estradiol is low levels [15]. It will affect on hormone regulation.

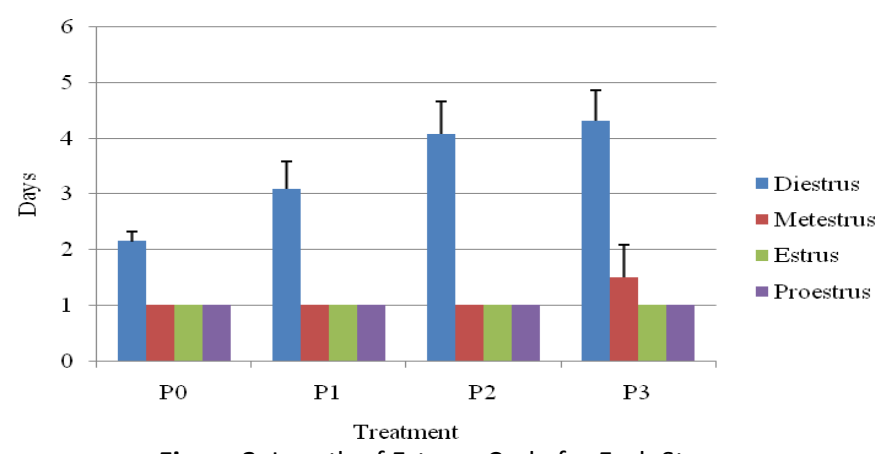

Figure 3. Length of Estrous Cycle for Each Stage 


\section{CONCLUSION}

The protein in the bull's sperm CSE have molecule size ranging from 26.8 to $176.8 \mathrm{kDa}$. Our findings suggested that bull sperm CSE influences the mice estrous cycle, especially in diestrus period elongation. This provides vital prelimenary information for the usage of CSE as the candidate of immunocontraception for human. We infer that it is necessary to measure the estrogen blood level, the antibody formation in the blood and flowcytometry analysis to elucidate if there a TNF-a present in the blood.

\section{ACKNOWLEDGEMENT}

Authors would like to thank IBIKK program of Biosciences Laboratory, University of Brawijaya: ristek dikti 2014-2016 no. 0263/e5/2014 for supporting this research.

\section{REFERENCES}

[1] Domagala, A, M. Kurpisz. 2004. Identification of sperm immunoreactive antigens for immunocontraceptive purposes: a review. Reprod. Biol. Endocrinol. 2(11).

[2] Triana, I.N. 2007. Potensi antibodi spermatozoa terhadap spermatogenesis dan fertilisasi pada tikus putih. Berkala Penelitian Hayati. 12. 187-189.

[3] Khaltoon, M., A.R. Chaudhari, S. Ramji, S. Prajapati. 2011. Antisperm antibodies in primary and secondary infertile couples of Central India. Biomed. Res. 22(3). 295-298.

[4] Haidl, G. 2010. Characterization of fertility related antisperm antibodies a step towards causal treatment of immunological infertility and immunocontraseption. Asian J. Androl. 12. 793-794.

[5] Hill, J.A. 1993. Production and effect of cytokines on local immuno endocrine reproductive event in famale reproductive tract in local immunity in reproductive tract tissue. Griffin, P.D., P.M. Johnson (Eds). Oxford University Press.

[6] Balchak, S.H., J.L. Marcinkiewicz. 1999. Evidence for the presence of tumor necrosis factor alpha receptors during ovarian development in the rat. Biol. Reprod. 61. 15061512.

[7] Rice, V.M., R.W. Valerie, D.L. Sharon, F.T. Paul. 1996. Tumour necrosis factor-alpha inhibits follicle stimulating hormoneinduced granulosa cell oestradiol secretion in the human: dependence on size of follicle. Human Reprod. 11(6). 1256-1261.
[8] Poli, P.S. 2001. Apoptosis in Ovary as a Physiological Cell Death Mechanism. Scientific Paper. Department of Physiology, Faculty of Medicine, Wijaya Kusuma University. Surabaya.

[9] Johnson, M.H., B.J. Everitt. 1988. Essensial reproduction $3^{\text {rd }}$ Ed. Blackwell Scientific Publication: Oxford.

[10] Ciptadi, G., S. Rhayu, B. Siswanto, E.A. Wahyuni, Aulanni'am, N. Ihsan. 2013. Kompetensi aktivasi protein ekstrak spermatozoa pada oosit M-II kambing berdasarkan analisis profil intensitas kalsium $\left(\mathrm{Ca}^{2+}\right)$. Jurnal Kedokteran Hewan. 7(2).

[11] Fatchiyah, E.L. Arumingtyas, S. Widyarti, S. Rahayu. 2011. Biologi molekular: prinsip dasar analisis. Erlangga: Jakarta.

[12] Mutiati, E., S. Rahayu, G. Ciptadi. 2016. The response of folliculogenesis mice (Mus musculus) intraperitoneally injected with Crude Sperm Extract. Master Thesis. University of Brawijaya: Malang.

[13] Sasaki, S., Y. Tamaki, K. Nagata, Y. Kobayashi. 2011. Regulation of the estrous cycle by neutrophils via opioid peptides. The $J$. Immunol. 187. 774-780.

[14] Marcondes, F.K., F.J. Bianchi, A.P. Tanno. 2002. Detemination of the estrous cyclephase of rats: some helpful considerations. Braz. Arch. Biol. Techn. 4A. 600-614.

[15] Walmer, D.K., M.A. Wrona, C.L. Hughes, K.G. Nelson. 1992. Lactoferrin expression in the mouse reproductive tract during the natural estrous cycle: correlation with circulating estradiol and progesterone. Endocrinol. 131. 1458-1466. 